Kovalev, N. I., Osmolovskaya, M. S. \& Lovyagina, E. V. (1948). Gigiena i Sanit. I3, no. 3, p. 5 I.

Kylin, H. (1915). Hoppe-Seyl. Z. 94, 337.

Lapicque, L. (1919). C. R. Acad. Sci., Paris, 167, 1082.

Lunde, G. \& Lie, J. (1938). Hoppe-Seyl, Z. 254, 227.

Marshall, S. M., Newton, L. \& Orr, A. P. (1949). $\quad A$ study of certain British Seazeeds and their Utilization in the Preparation of Agar. London: H.M. Stationery Office.

Moncrieff, R. W. (1952). Food Tr. Rev. 22, I I.

Nilson, H. W. \& Lemon, J. M. (1942). Res. Rep. U.S. Fish Serv. 4, I.

Peat, S., Thomas, G. J. \& Whelan, W. J. (1952). F. chem. Soc. p. 722.

Percival, E. G. V. \& Ross, A. G. (1949). F. chem. Soc. p. 3041.

Saiki, R. (1906). F. biol. Chem. 2, 251.

Schmidt. C. (1844). Ann. Chem. Pharm. 5r, 29.

Sheehy, E. J., Brophy, J., Dillon, T. \& O'Muineachian, P. (1942). Econ. Proc. R. Dublin Soc. 3, no I2, p. 150.

Swartz (1946). Colloid Chemistry, Vol. 6, p. 700. [J. Alexander, editor.] New York : Reinhold Publishing Corp.

Takahashi, E., Shirahama, K. \& Tase, S. (1933). F. chem. Soc. Fapan, 54, 619.

Takahashi, E., Shirahama, K. \& Tase, S. (1935). F. chem. Soc. Fapan, 56, 1250.

Todd, W. R., Myers, J. \& West, E. S. (1939). F. biol. Chem. 127, 275.

Tseng, C. K. (1946). Colloid Chemistry, Vol. 6, p. 629. [J. Alexander, editor.] New York : Reinhold Publishing Corp.

Woodward, F. N. (1952). Industr. Chem. Mfr. 28, 341.

\title{
Mushrooms and Toadstools
}

\section{By J. Ramsвoтtom, Department of Botany, British Museum, London}

I must confess that I have only a layman's knowledge of nutrition : I have probably been invited to join in this symposium because it is almost only in this country that fungi are regarded as an unusual food. For the most part we are content with the cultivated mushroom where purchase is felt to ensure security. Country people gather the field mushroom ; to a townsman the eating of it is a bold adventure. The easily recognized blewits (Tricholoma personatum) is eaten in the midlands and north and is sold in the markets ; the morel (Morchella esculenta) is used in the north for flavouring soups and gravies.

The modern British attitude towards fungi is difficult to understand. One factor is doubtless the comparative lack of forests, where most of the larger species have their habitats : another the fact that until recently there was an abundance of other food : a third appears to be tradition.

The evidence from former times is somewhat contradictory. Nothing is known about the views of early Britons. The Romans were fond of fungi and would certainly not have disregarded those they knew when they landed here. Though there is much praise of them in both Greek and Roman writings, great stress is laid on the accidents they caused, and it was known that they were convenient for administering poison. Dioscorides in De materia medica classified fungi into those edible and those poisonous. At the revival of learning the chief aim of the herbalists was to elucidate Dioscorides. They accepted his grouping but added accounts of the 'funest accidents' which the ancients had reported presumably as news. Our two chief herbals give conflicting accounts about English usage. 
Gerard (I597) says many ' doe hunger after the earthie excrescences, called Mushrums . . . few are good to be eaten; and most of them do suffocate and strangle the eater'. Parkinson ( 1640 ) states that his readers need not be cautioned against dangerous mushrooms 'seeing our nation is not so inclined to the food'.

Two medieval recipes may be mentioned-Richard II's master cook's The Forme of Cury (1390) gives one 'Take funges, and pare hem', while a 9 th or roth century recipe for making a woman pregnant says ' and for meat she shall eat mushrooms'. Evelyn (1699), says that he would have preferred to omit fungi from his Discourse on Sallets but they were 'so highly contended for by many, as the very principal and top of all the rest . . . at no small charge we send for them into France, as we also do for Truffles ... . rank and poisonous excrescences'. The fungi from France were probably cultivated mushrooms which Martin Lister ( 1698 ) says were then grown about Paris.

I believe credence can be given to W. Harrison's ( 1577 ) statement in Holinshed's Chronicles: 'The English eat dangerous fruits, like Mushrooms'. Further it seems probable that a misreading of the classics led to the fear of dread mischance, particularly as it was not certain which species caused trouble. Indeed it was this which inspired the ancient writers to give lists of characteristics by which to distinguish the good from the evil-the latter did not peel, turned silver black, emitted coloured juice, grew near rusty nails or serpents' holes and so on. Many are still believed in, particularly the first two, but all are worthless. Only one practical test is infallible, and that is not to be recommended. About 80 years ago five or six species were sold in Covent Garden Market but opinion gradually became fixed ; there is one edible fungus which is sold in the shops, the rest are deadly poisonous. Indeed, even now, the position is such that one cannot consider fungi as food without dealing with this widespread fear. The fact is that there are fewer poisonous species of fungi than there are of flowering plants. Almost all the deaths have been due to Amanita phalloides, the death cap. This common species and the two rare, closely related $A$. verna and $A$. virosa are our only deadly poisonous species. The symptoms of poisoning are terrible, the list reading like the twenty-nine distinct damnations of the Galatians. The poisoning is due to three substances, $\alpha$-amanitine, $\beta$-amanitine and phalloidin. Amanitine, a polypeptide with an indol group, has the formula $\mathrm{C}_{33} \mathrm{H}_{45(47)} \mathrm{O}_{12} \mathrm{~N}_{7} \mathrm{~S}$; it is slow acting, causing hypoglycemia and caryolysis. Phalloidin is a hexapeptide with the formula $\mathrm{C}_{30} \mathrm{H}_{39} \mathrm{O}_{9} \mathrm{~N}_{7} \mathrm{~S}$; it is weaker but more rapid in its action than amanitine, causing degeneration of the liver, kidney and cardiac muscle. Phalline which was isolated as early as in $I 89 \mathrm{I}$ and at first thought to be the active principle is a glucoside having the formula $\mathrm{C}_{50} \mathrm{H}_{6} \mathrm{O}_{22} \mathrm{~N}_{10} \mathrm{~S}$; it causes haemolysis and is rapidly destroyed by heat.

Amanita muscaria, the fly agaric, is the one toadstool which most people can recognize and which is generally regarded as the most poisonous because of its bright red cap. It is not, however, deadly. Muscarine was first isolated from it but usually occurs in very small amounts. The characteristic symptoms of cerebral excitement are due to mycetoatropine. A. pantherina has the same poisons and 
produces similar symptoms though it is reputed to be somewhat more dangerous.

Several species of Clitocybe and Inocybe contain muscarine in amounts sufficient to cause intensive sweating.

For the rest, there are Entoloma lividum, Boletus Satanas and Gyromitra esculenta which are reported to have caused trouble. Some species like the Yellow Staining Mushroom (sometimes to be seen in London shops) are very indigestible and cause regrets to some of those who partake of them. If allergy is disregarded, it is I believe a fair statement to say that of the toadstools that are of a size and consistency to warrant trial less than a dozen could be considered in any way harmful, when cooked.

In this country there is no real need to look to fungi for nutriment but it is not always so elsewhere. According to Darwin, the natives of Tierra del Fuego eat as their sole vegetable food, except for a few berries, the fungus Cyttaria Darwinii which grows in vast quantities on beech. In New Guinea there is a small caveinhabiting tribe whose food consists of fungi and palm sprouts, and what rats and mice they can catch with their hands.

F. Schwaegrichen, Professor of Botany at Leipzig towards the end of the 18 th century, finding that the people about Nüremberg subsisted entirely on fungi and black bread, experimented with the diet for several weeks; he suffered no ill effects and indeed felt stronger. He concluded that fungi if used moderately are very nutritious but that they lose their flavour in cooking.

In countries with severe winters where it is impossible for the peasants to obtain vegetables, fungi are collected in the autumn and dried, or pickled in brine. In religious sects where the eating of meat is forbidden at certain times, great use is made of fungi. This was particularly so during the three great fasts of the Russian Church.

Further, it has been known from the time of Ludovico de Varthema (1503-8) that the truffle (Kames) is eaten in great quantities in Asia Minor. Dickson (1949) says 'Truffles and mushrooms, great delicacies to every Badawin ... form the staple food of the tent-dweller and his family for weeks on end'.

In the two world wars fungi were much sought after by starving peoples on the Continent. Refugees to this country were often amazed at our total disregard of fungi they knew as delicious food.

During the first war fungi were found most valuable in the French Cameroons, and the German forces constantly on the run in the East Africa campaign were often compelled to exist almost entirely on them. von Lettow-Vorbeck (I919) says they were to them as manna was to the children of Israel : "though fungi, as sole diet were somewhat indigestible and not very strengthening, yet they were to us of very real help'.

Those who have visited Continental markets or who have eaten in the restaurants need no reminding that fungi are bought, and eaten with enjoyment. In most markets there is some method of 'vetting' those offered for sale.

Toadstools in woods often show the teeth marks of squirrels and rabbits and, very occasionally, one catches sight of these animals nibbling the caps. My 
impression is that though Boletus is most commonly marked, no fleshy species is wholly avoided, even Amanita phalloides; experiments have shown that the rabbit can eat small quantities of this fungus without ill effects, its stomach contents neutralizing the poisons. Hastings \& Mottram (1917), experimenting with tame rabbits, found that they would take some species as food, additional ones when moderately hungry, and still others as hunger increased. Slugs are ardent mycophagists, and thrive on $A$. phalloides.

Apparently most wild animals will eat fungi though the lack of references might lead to the assumption that native animals subscribe to the national phobia. However, cows, sheep and horses occasionally eat field mushrooms, deer eat Boletus, as also do pigs-the Latin name for the fungus was suillus - and pigs root up truffles even when there is no human interest in their performance. Worthington Smith (I865) records that his tame rabbits ate the spongy stems of Phallus ; my daughter's long-haired dachshund, nice about his food, had a great liking for Coprinus atramentarius ; young turkeys eat Lepiota procera.

In Finland and Norway cattle have to be prevented from wandering into the woods for Boletus - the late J. L. Chaworth-Musters, who had a farm in Norway, told me that the cows 'go mad about Boletus edulis and B. scaber which are known as "Kusop " i.e. cow-fungus'. It is likely that by the time of the fungus season pastures are beginning to thin out-and cattle are not so fenced in as here. Fungi, either fresh, dried or salted, are fed to cattle in several European Countries, or added to fodder in place of fish meal. It has recently been ascertained that toadstools form an important part of reindeer food : in winter they dig up frozen specimens.

There has always been controversy about the nutritive value of mushrooms and toadstools much of it apparently tinged with psychology : they have been said to be as good as or even better than beef and, on the other side, at most worthless. The second is obviously an exaggeration.

Perhaps it would be well to define my own position in these matters. It is probably 40 years ago that I first lectured on edible and poisonous fungi, and in the Handbook of the Larger British Fungi (Ramsbottom, 1923) I indicated edible, poisonous and suspicious species-even using this as a general basis of selection. Soon after the outbreak of the last war when rations began to be monotonous, when the price of cultivated mushrooms soared until in London it eventually reached I $6 /-$ a pound, and when refugees startled the natives by gathering and eating toadstools locally that were believed to be deadly poisonous, I thought it well to stress that toadstools just as savoury as the cultivated mushroom are common in our woods and pastures and that the best are so characteristic that they cannot be confused. There was never any campaign to persuade people to eat toadstools-but thousands did without, so far as I know, a single mishap.

There have been many chemical analyses of different species over the years. Apart from the usual discrepancies, there are variations between the species, as would be expected. Comparison is sometimes difficult because many of the 
analyses are of dried material : it is probably such analyses that have misled some writers into drawing too favourable conclusions about nutritive values.

It would serve no useful purpose to give details of numerous analyses so I have lumped together ten different well known edible species and made a summary of their percentage composition :

\author{
Water \\ Nitrogenous materials \\ Carbohydrates : \\ Cellulose and chitin \\ Fat \\ Sugars (trehalose, mannitol) \\ Minerals
}

$\begin{array}{ccc}84-92 & \text { (average } 89.2 \text { ) } \\ \mathrm{r} \cdot 31-5.39 \text { (average } & 3.0 \text { ) } \\ & \\ 0.91-9.14 & \text { (average } & 4 \cdot 2 \text { ) } \\ 0.79-2 \cdot 18 \text { (average } & \mathrm{I} \cdot 09 \text { ) } \\ 0.20-0.76 \text { (average } & 0.44 \text { ) } \\ 0.45^{-1} \cdot 12 \text { (average } & 0.82 \text { ) }\end{array}$

The minerals are chiefly potassium and phosphoric acid (as lecithin), with small and varying amounts of sodium, calcium, magnesium, iron, manganese, aluminium, silicon, sulphur and chlorine, principally in the skin of the cap.

Of the nitrogenous material $45 \cdot 4-84 \%$ (av. 66.8\%) is assimilable, and about $95 \%$ of the carbohydrate. Lintzel (I94I) experimenting with Psalliota campestris, Cantharellus cibarius and Boletus edulis found they yielded proteins with a mean digestibility corresponding to $72-83 \%$ of the total nitrogen. For maintenance of nitrogen equilibrium in a normal person weighing $70 \mathrm{~kg}$, from 43 to $62 \mathrm{~g}$ of total nitrogenous substance, corresponding to $100-200 \mathrm{~g}$ dried mushroom, were necessary if mushrooms were used as the sole source of protein.

Some attention has been paid to the vitamin content of the larger fungi, but little in comparison with moulds and yeasts. Willstaedt (194I) investigated twelve different edible species for carotene, thiamine, riboflavin and ascorbic acid by chemical methods. The only good source of thiamine was Lactarius deliciosus with 37 i.u./100 g. This species, Psalliota sylvatica, Cantharellus cibarius, Boletus luteus, Tricholoma nudum and Hygrophorus conicus contained $160-690 \mu \mathrm{g}$ riboflavin/ $100 \mathrm{~g}$. Cantharellus cibarius contained about $16 \mathrm{mg}$ ascorbic acid/100 $\mathrm{g}$ but the other eleven species only 2-4 mg.

In a previous investigation Willstaedt (1937) had examined three species of Cantharellus for carotenoids. In $C$. cibarius he found mainly $\beta$-carotene $(4 \mathrm{mg} /$ Ioo g) and small amounts of $\alpha-, \gamma$ - and $\delta$-carotenes, and lycopene.

Willstaedt concluded that, in general, toadstools could not be considered as a valuable source of vitamins.

Toadstools generally seem to be poor in ascorbic acid though there are indications that some species contain it in non-negligible amounts.

Fungi as a whole are rich in ergosterol though vitamin $\mathrm{D}$ is, curiously, infrequent. Amongst the larger fungi it has been recorded for Psalliota campestris, Boletus edulis, Cantharellus cibarius, C. clavatus, Hydnum imbricatum, Morchella esculenta and Gyromitra gigas. Marasmius oreades presumably contains it as it gives antirachitic action when fed to rabbits. Scheunert, Reschke \& Schieblich (1935) 
found that Boletus edulis contained 0.83 i.u./g, Cantharellus cibarius 0.83 , Gyromitra esculenta $\mathrm{I} \cdot \mathrm{I} 2$, Psalliota campestris (grown in dark) $0 \cdot \mathrm{I} 2$ (in light) 0.62 .

Perhaps it would be well to end with the cultivated mushroom. It should be pointed out that there is doubt when the name Psalliota campestris is used. This name should be restricted to the field mushroom which is now known to be a different species from the forms under cultivation. It is probably safe to assume that the cultivated species $-P$. hortensis $(P$. bispora) - has been studied in experiments on nutrition unless the contrary is stated. Anderson \& Fellers (1942) found that commercially cultivated $P$. campestris contained in $\mathrm{mg} / 100 \mathrm{~g}$ :

$\begin{array}{llll}\text { Vitamin A } & \text { None } & \text { Vitamin D } & \text { None } \\ \text { Thiamine } & 0.12 & \text { Vitamin K } & ++ \\ \text { Riboflavin } & 0.52 & \text { Nicotinic acid } & 5.85 \\ \text { Ascorbic acid } & 8.60 & \text { Pantothenic acid } & 2.38\end{array}$

Potassium and phosphorus salts are the chief constituents of the ash, with no significant amounts of calcium but with copper and iron in appreciable amounts. Rats receiving mushrooms as the sole source of protein in their diet survived a 6-week test period and made a gain in weight equivalent to $30 \%$ of that shown by rats on a casein diet. One further point, Friese (1948) concluded that provided sound mushrooms are used they can be cooked and held overnight in a refrigerator without fear of anything untoward.

\section{REFERENCES}

Anderson, E. E. \& Fellers, C. R. (1942). Proc. Amer. Soc. hort. Sci. 4r, 30 r.

Dickson, H. R. P. (1949). The Arab and the Desert. London.

Evelyn, J. (1699). Acetaria. A Discourse on Sallets. London.

Friese, W. (1948). Z. LebensmittUntersuch. 88, I4.

Gerard, J. (I597). The Herball.

Harrison, W. (1577). Description of England in Holinshed R. Chronicles. London.

Hastings, S. \& Mottram, J. C. (1917). Trans. Brit. mycol. Soc. 5, 364.

Lintzel, W. (r94I). Biochem. Z. 308, 413.

Lister, M. (1698). Fourney" to Paris. London.

Parkinson, J. (1640). Theatrum Botanicum : the Theater of Plants : or an Herball of a Large Estate. London.

Ramsbottom, J. (1923). A Handbook of the Larger British Fungi. London: The Trustees of the British Museum.

Scheunert, A., Reschke, J. \& Schieblich, M. (I935). Hoppe-Seyl. Z. 235, 9 I.

Smith, W. G. (1865). F. Bot., Lond., 2, 217.

von Lettow-Vorbeck (1919). Meine Erinnerungen aus Ostafrika.

Willstaedt, H. (1937). Svensk kem. Tidskr. 48, 306.

Willstaedt, H. (I94I). Svensk kem. Tidskr. 53, 23.

\section{Insects as Food}

\section{By W. S. Bristowe, Beech Hanger, Langton Green, Tunbridge Wells}

When dining with friends a few years ago I was invited to play a card game and found to my embarrassment that, in changing my clothes, I had left all my money at home. Just at that moment I noticed a small House Spider (Tegenaria atrica) running across the carpet, so I seized it and offered to eat it alive in return for 